\title{
चUSGS
}

science for a changing world

U.S. DEPARTMENT OF THE INTERIOR

U.S. GEOLOGICAL SURVEY

\section{BEDROCK GEOLOGIC MAP OF THE YUCCA MOUNTAIN AREA, NYE COUNTY, NEVADA}

By

Warren C. Day, 1 Robert P. Dickerson, 2 Christopher J. Potter, 1 Donald S. Sweetkind, 1 Carma A. San Juan,2 Ronald M. Drake II,2 and Christopher J. Fridrich1

1998

1U.S. Geological Survey, Denver, Colorado

2Pacific Western Technologies, Inc., Denver, Colorado

Prepared in cooperation with the

NEVADA OPERATIONS OFFICE, U.S. DEPARTMENT OF ENERGY

Pamphlet to accompany

GEOLOGIC INVESTIGATIONS SERIES 
1 


\section{CONTENTS}

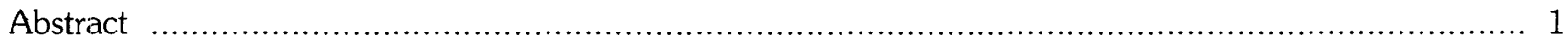

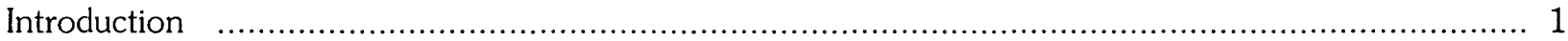

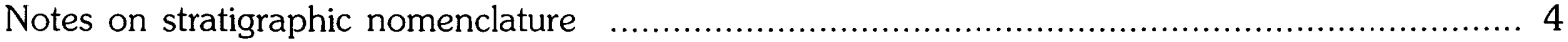

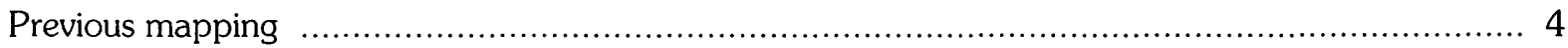

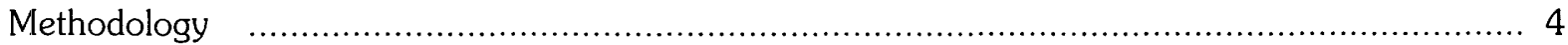

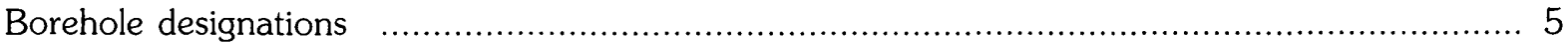

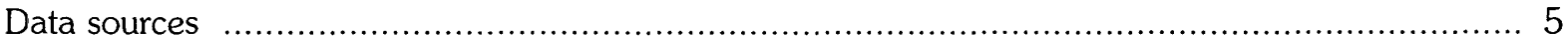

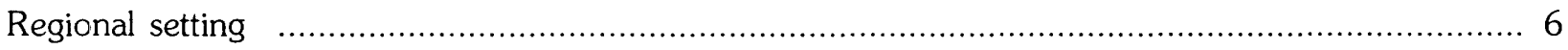

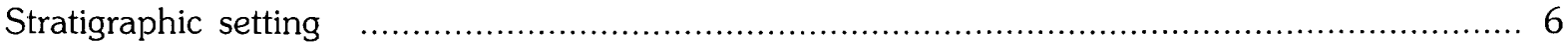

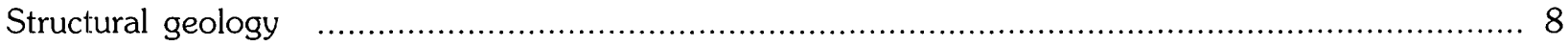

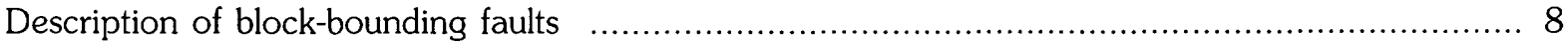

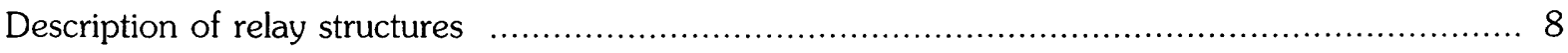

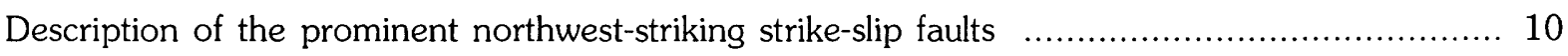

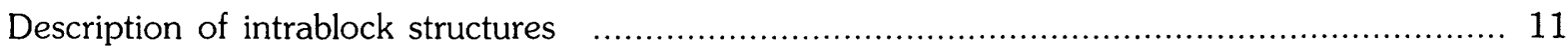

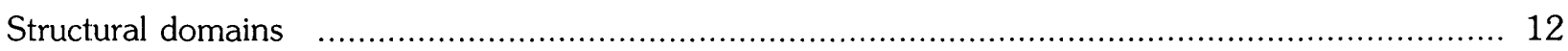

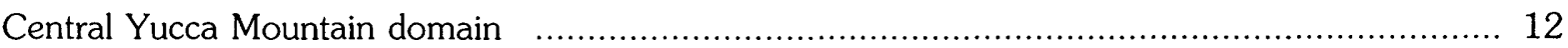

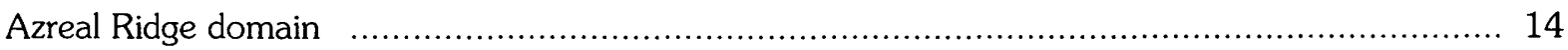

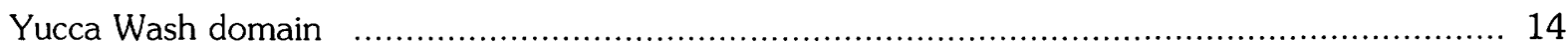

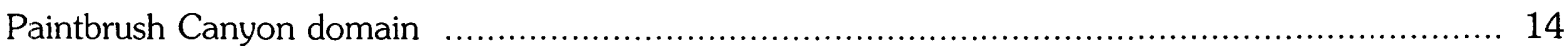

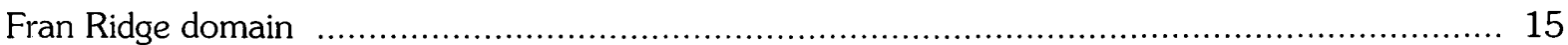

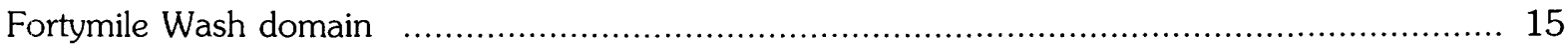

Plug Hill domain

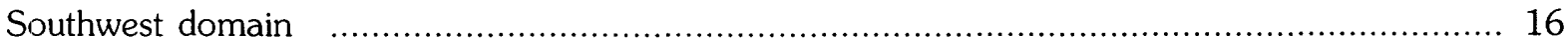

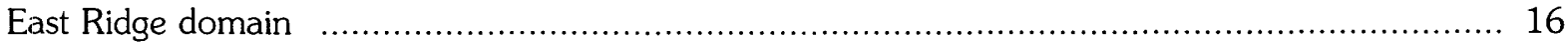

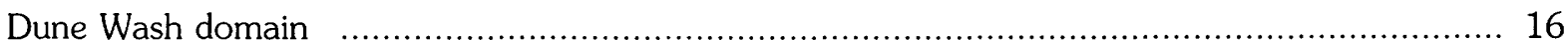

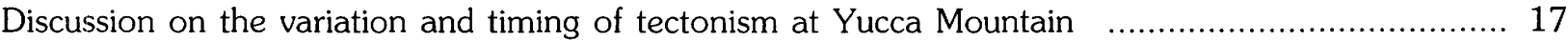

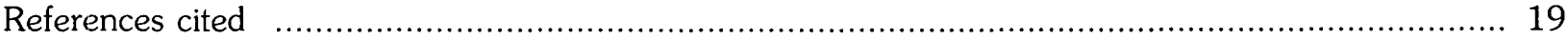




\section{FIGURES}

1. Index map of study area showing regional distribution of caldera structures near Yucca

2 Mountain, Nye County, Nevada.

2. Map showing locations of prominent physiographic features in the map area 3

3. Map showing distribution of fault types in the map area 9

4. Map showing distribution of structural domains defined for the map area 13

CONVERSION FACTORS

\begin{tabular}{lll}
\hline Multiply & by & To obtain \\
\hline millimeter $(\mathrm{mm})$ & 0.03937 & inch (in.) \\
centimeter $(\mathrm{cm})$ & 0.3937 & inch (in.) \\
meter $(\mathrm{m})$ & 3.281 & foot (ft) \\
kilometer $(\mathrm{km})$ & 0.6214 & mile (mi) \\
\hline
\end{tabular}

The following abbreviation is also used in this report:

$\mathrm{Ma}$, millions of years before present. 


\section{ABSTRACT}

Yucca Mountain, Nye County, Nevada, has been identified as a potential site for underground storage of high-level radioactive nuclear waste. Detailed bedrock geologic maps form an integral part of the site characterization program by providing the fundamental framework for research into the geologic hazards and hydrologic behavior of the mountain. This bedrock geologic map provides the geologic framework and structural setting for the area in and adjacent to the site of the potential repository.

The study area comprises the northern and central parts of Yucca Mountain, located on the southern flank of the Timber Mountain-Oasis Valley caldera complex, which was the source for many of the volcanic units in the area. The Timber Mountain-Oasis Valley caldera complex is part of the Miocene southwestern Nevada volcanic field, which is within the Walker Lane belt. This tectonic belt is a northwest-striking megastructure lying between the more active Inyo-Mono and Basin-and-Range subsections of the southwestern Great Basin.

Excluding Quaternary surficial deposits, the map area is underlain by Miocene volcanic rocks, principally ash-flow tuffs with lesser amounts of lava flows. These volcanic units include the Crater Flat Group, the Calico Hills Formation, the Paintbrush Group, and the Timber Mountain Group, as well as minor basaltic dikes. The tuffs and lava flows are predominantly rhyolite with lesser amounts of latite and range in age from 13.4 to $11.6 \mathrm{Ma}$. The 10-Ma basaltic dikes intruded along a few fault traces in the northcentral part of the study area.

Fault types in the area can be classified as block bounding, relay structures, strike slip, and intrablock. The block-bounding faults separate the 1- to 4-km-wide, east-dipping structural blocks and exhibit hundreds of meters of displacement. The relay structures are northweststriking normal fault zones that kinematically link the block-bounding faults. The strike-slip faults are steep, northwest-striking dextral faults located in the northern part of Yucca Mountain. The intrablock faults are modest faults of limited offset (tens of meters) and trace length (less than $7 \mathrm{~km}$ ) that accommodated intrablock deformation.

The concept of structural domains provides a useful tool in delineating and describing variations in structural style. Domains are defined across the study area on the basis of the relative amount of internal faulting, style of deformation, and stratal dips. In general, there is a systematic north to south increase in extensional deformation as recorded in the amount of offset along the block-bounding faults as well as an increase in the intrablock faulting.

The rocks in the map area had a protracted history of Tertiary extension. Rocks of the Paintbrush Group cover much of the area and obscure evidence for older tectonism. An earlier history of Tertiary extension can be inferred, however, because the Timber Mountain-Oasis Valley caldera complex lies within and cuts an older north-trending rift (the KawichGreenwater rift). Evidence for deformation during eruption of the Paintbrush Group is locally present as growth structures. Post-Paintbrush Group, pre-Timber Mountain Group extension occurred along the block-bounding faults. The basal contact of the 11.6-Ma Rainier Mesa Tuff of the Timber Mountain Group provides a key time horizon throughout the area. Other workers have shown that west of the study area in northern Crater Flat the basal angular unconformity is as much as $20^{\circ}$ between the Rainier Mesa and underlying Paintbrush Group rocks. In the westernmost part of the study area the unconformity is smaller (less than $10^{\circ}$ ), whereas in the central and eastern parts of the map area the contact is essentially conformable. In the central part of the map the Rainier Mesa Tuff laps over fault splays within the Solitario Canyon fault zone. However, displacement did occur on the block-bounding faults after deposition of the Rainier Mesa Tuff inasmuch as it is locally caught up in the hanging-wall deformation of the block-bounding faults. Therefore, the regional Tertiary to Recent extension was protracted, occurring prior to and after the eruption of the tuffs exposed at Yucca Mountain.

\section{INTRODUCTION}

This 1:24,000-scale map focuses on the area surrounding the potential high-level nuclear waste repository site at Yucca Mountain (figs. 1 and 2). Its purpose is to define the character and extent of the dominant structural features in the vicinity of and outward from the potential repository area. As currently conceived, the potential repository would be a permanent underground facility with high-level nuclear waste placed in drifts excavated in the densely welded units of the Miocene Topopah Spring Tuff. The repository would be built in the unsaturated zone approximately $250 \mathrm{~m}$ above the regional groundwater table. The Yucca Mountain Project currently is evaluating the cumulative effect of natural geologic hazards in the site area, including seismic and volcanic hazards. Hydrologic investigations and computer-aided three-dimensional 


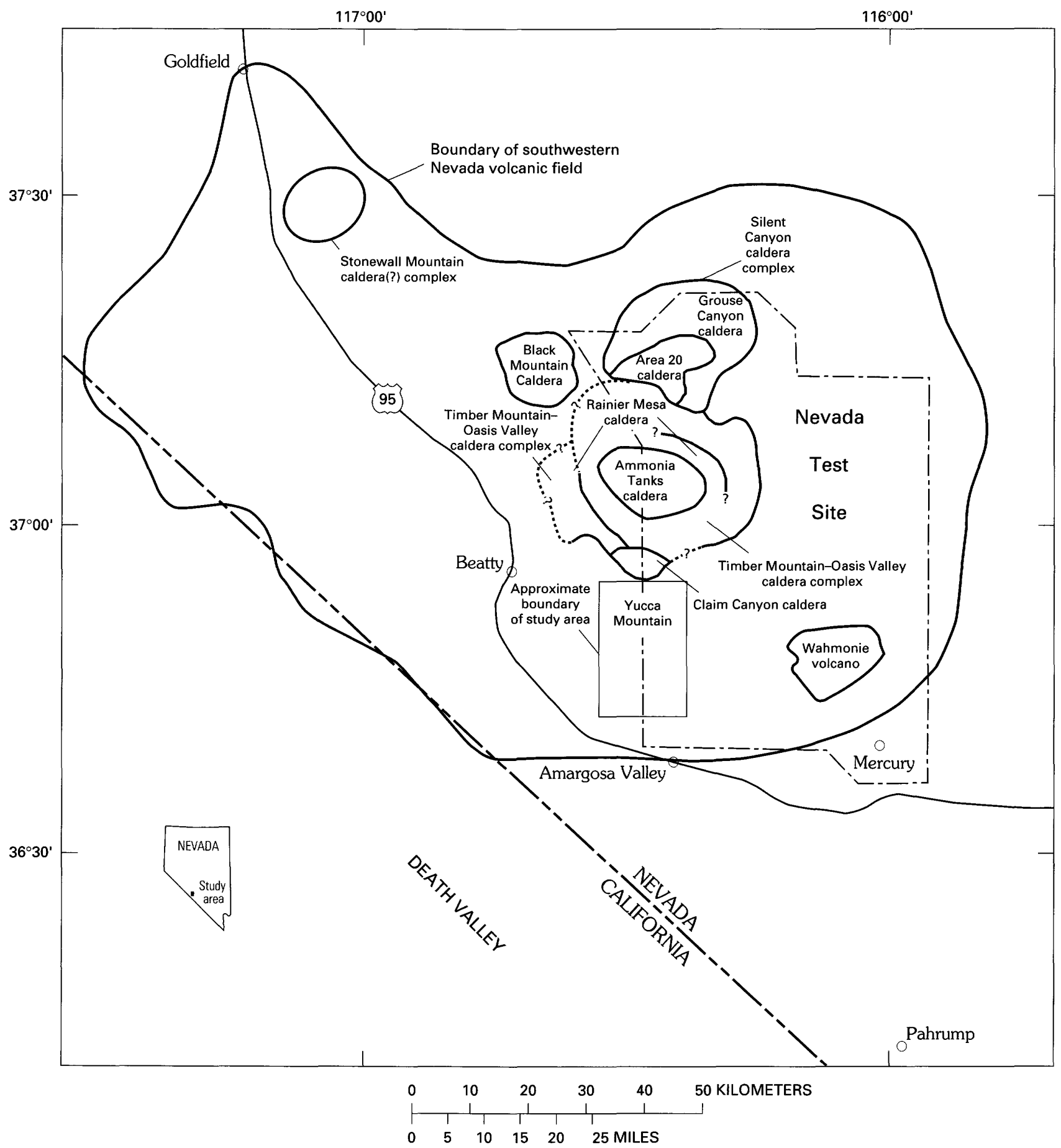

Figure 1. Index map of study area showing regional distribution of caldera structures near Yucca Mountain, Nye County, Nevada. Modified from Carr and others (1986, fig. 1) and Sawyer and others (1994, fig. 1). 

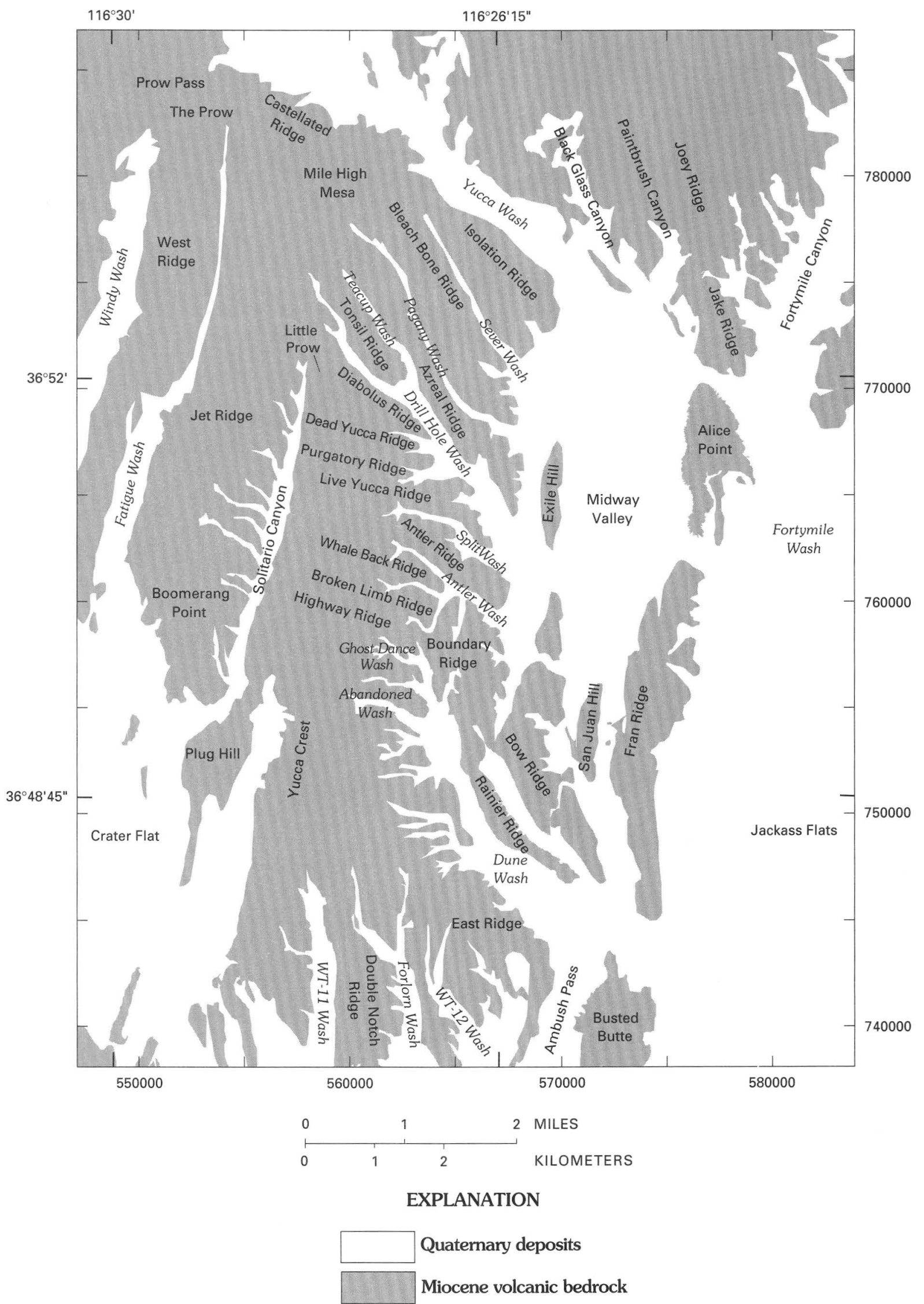

Figure 2. Locations of prominent physiographic features in the map area. 
geologic and hydrologic framework modeling efforts are ongoing to characterize the site as fully as possible. Knowledge of the distribution of geologic units as well as the stratigraphic and structural setting is the underpinning for such investigations. This map and accompanying text describe the location, geometry, and kinematic interplay between the various fault types as well as variations in the structural style. The concept of structural domains is applied to the map area to better describe these structural variations. The timing of deformation at Yucca Mountain is discussed in the context of the Tertiary to Recent tectonic evolution for the area.

\section{NOTES ON STRATIGRAPHIC NOMENCLATURE}

The stratigraphic nomenclature used here is modified from the informal stratigraphy presented by Buesch and others (1996), incorporating lessons learned by Day and others (1998). The stratigraphic nomenclature presented in Buesch and others (1996) was an outgrowth of borehole studies, replacing map units of Scott and Bonk (1984) from a volcanological perspective to reflect stratigraphic features observed both in the boreholes and outcrops. Buesch and others (1996) also incorporated the work of Sawyer and others (1994) to update definitions of formations and groups for the area. Modifications to the nomenclature used herein were made to simplify the map unit labels to the standard maximum of four letters per unit, which was especially necessary in the structurally complex areas of the map. The " $\mathrm{T}$ " used by Buesch and others (1996) was dropped from the bedrock igneous rock unit labels inasmuch as they are all Tertiary in age. In addition, the " $p$ " for most of the units in the Paintbrush Group (see Buesch and others, 1996) was dropped. For example, a unit such as the middle nonlithophysal zone of the crystal-poor member of the Topopah Spring Tuff, delineated as "Tptpmn" by Buesch and others (1996), is simplified to "tpmn" in this report. This convention follows that for symbols for standard U.S. Geological Survey geologic maps as outlined by Hansen (1991).

\section{PREVIOUS MAPPING}

During the 1960's Lipman and McKay (1965) and Christiansen and Lipman (1965) mapped the Yucca Mountain area at a scale of $1: 24,000$ during a regional mapping campaign to provide an overall geologic framework for the Nevada Test Site. They delineated the main block-bounding faults and some of the intrablock faults, and outlined the zoned compositional nature of the tuffaceous units that underlie Yucca Mountain. After identification of Yucca Mountain as a possible site for high-level nuclear waste disposal by the U.S. Department of Energy, during the 1980's Scott and Bonk (1984) developed a detailed reconnaissance $(1: 12,000$ scale) geologic map of the area. This map was used to help constrain the most favorable area at Yucca Mountain and was a guide to further site-characterization studies. Of their many contributions, Scott and Bonk (1984) presented a detailed stratigraphy for the volcanic units, further defined the block-bounding faults, and mapped numerous intrablock faults.

Subsequent mapping during the 1990's revealed structural complexities along some of the intrablock faults (for example, Spengler and others, 1993) not evident at the 1:12,000 scale. Recently, Day and others (1998) developed a detailed (1:6,000 scale) geologic map over the central block area, which includes the potential repository (see fig. 4). A detailed (1:6,000 scale) geologic map of the area north of Yucca Wash in the Paintbrush Canyon area has just been completed (Dickerson and Drake, 1998) and was incorporated herein.

\section{METHODOLOGY}

This map was developed using standard geologic mapping techniques. Detailed 1:6,000scale and 1:12,000-scale orthophoto and topographic maps were used for base maps over most of the area, which were developed specifically for the Department of Energy Yucca Mountain Project. These series of maps have $10-\mathrm{ft}$ contour intervals. As such, the final product used supporting maps at a much larger scale $(1: 6,000$ to $1: 12,000)$ than the final $1: 24,000$ scale map.

Stratigraphic units within the Topopah Spring and Tiva Canyon Tuffs, which make up the bulk of bedrock outcrops in the map area, have been refined into informal members, zones, and subzones by Buesch and others (1996) (see "Stratigraphic setting" section). Inasmuch as the Topopah Spring Tuff is proposed as the host unit for the potential repository, the present map includes detailed zonal subdivisions of the Topopah where possible. In order to simplify the final map, the Tiva Canyon Tuff was mapped at the informal member status [crystalrich and crystal-poor members (units $\mathrm{cr}$ and $\mathrm{cp}$ )], as was its nonwelded basal vitric zone (unit $\mathrm{cpv}$ ), which forms a prominent marker horizon throughout the map area. 
The threshold vertical offset on faults mapped outside of the central block area (Day and others, 1998) was approximately $10 \mathrm{ft}(3$ $\mathrm{m})$. Within the central block proper, the threshold was approximately $5 \mathrm{ft}(1.5 \mathrm{~m})$ of vertical offset. Placement of stratigraphic contacts falls within similar vertical thresholds of accuracy. In addition, detection of faults is difficult within the middle part of the crystal-poor member of the Tiva Canyon Tuff. This zone is one of the most widely exposed units, but it commonly forms debris-covered slopes. Faults are difficult to detect in this unit not only because of the cover, but because it is a densely welded unit that lacks internal marker horizons. However, faults that offset adjacent mappable contacts are easier to detect. As such, the intrablock faults with a few hundred meters or more of surface trace length were readily detected. In this same vein, the massive, densely welded middle nonlithophysal zone of the crystal-poor member of the Topopah Spring Tuff (unit tpmn) may contain minor faults that were undetected. Faults with appreciable extent cut through map unit contacts, however, which are offset. Their presence would have been detected.

\section{BOREHOLE DESIGNATIONS}

Each borehole depicted on the map and used in the study of Yucca Mountain has a unique name or number. For the purposes of this report the prefix designators UE-25 or USW (see following paragraphs) are not posted on the map because of space limitations on the map. Each bolehole designator is unique in this study area, and, therefore, the prefixes are not necessary on the map.

Boreholes on the Nevada Test Site (NTSsee geologic map for boundary) use a designation that differs slightly from that of boreholes off the NTS. For example, the full borehole designations for boreholes on the NTS begin with UE (for Underground Exploratory), followed by the NTS area number (Area 25 in this report; for example, UE-25). This prefix designation "UE-25" commonly is followed by one or more letters signifying the purpose of the hole or simply by a sequential letter, followed by a sequence number. Thus, the designation "UE-25 c\#3" specifies a hole on the NTS in Area 25 and that it is the third hole planned, but not necessarily drilled, at a site named "c".

For boreholes off the NTS in adjacent land to the west controlled by the U.S. Bureau of Land Management or the Nellis Air Force Range, the prefix USW is used (for Underground, Southern Nevada, Waste). For USW boreholes, the series identifier and sequence number are separated by a hypen rather than the number symbol, \#. The first hole planned in the UZ series is off-NTS and, therefore, is designated "USW UZ-1".

The letters signify the primary purpose for which the borehole was drilled. For example, boreholes starting with $\mathrm{G}$ were drilled for collection of geologic data, those with $\mathrm{H}$ were drilled primarily for hydrologic data, with $U Z$ for unsaturated zone data, with NRG for collection of data along the north-ramp alignment of the underground Exploratory Studies Facility (ESF), with $p$ for collection of data on rocks of preTertiary age, with SD for geotechnical and hydrologic data from a statistically located systematic drilling program, and with WT for testing the depth of the water table.

\section{DATA SOURCES}

Two geologic map reports were incorporated into this map (see "Index to geologic mapping" on map): the bedrock geologic map of the central block area by Day and others (1998) and the geologic map of the Paintbrush Canyon area by Dickerson and Drake (1998). The remaining area was remapped by the authors (W.C. Day, R.P. Dickerson, C.J. Potter, D.S. Sweetkind, and R.M. Drake, II) from June 1996 through June 1997, and by C.J. Fridrich during 1992.

The locations of faults beneath the Quaternary surface deposits of Midway Valley and Yucca Wash were inferred from the groundbased gravity and magnetic surveys of Langenheim and others (1993), Langenheim and Ponce (1994), Ponce and others (1993), and Ponce (1993). A recent geophysical report on the Midway Valley and Yucca Wash areas by Ponce and Langenheim (1994) was also included. All of these sources were used primarily to determine the probable location of the concealed faults in Midway Valley and Yucca Wash, as well as to estimate the direction of offset. Estimates of offset were also corroborated by Buesch and others (1994).

The main source of information for the structural control on the interpretations presented in the cross sections was the surface geologic mapping presented herein. Stratigraphic thickness information from Geslin and Moyer (1995), Geslin and others (1995), Moyer and others (1995), and Moyer and others (1996) was used as corroborative data to compare with outcrop data to construct the cross sections. Data from three-dimensional computer framework models by Buesch and others (1995) and from the Integrated Site Model ISM2.0 by 
R.W. Clayton and W.P. Zelinski (WoodwardClyde Federal Services, written commun., 1997) were also used as corroborative information to verify stratigraphic thicknesses on the cross sections.

Over the decades of geologic investigations at Yucca Mountain, numerous cross sections of the Midway Valley area have been produced, each reflecting the geologic understanding at that time. These corroborative cross sections include those of Scott and Bonk (1984), Scott (1990), Carr (1992), Carr and others (1986), Geldon (1993), and Neal (1986) as well as unpublished cross sections by W.R. Keefer and J.W. Whitney (U.S. Geological Survey, written commun., 1996), and geophysical interpretations by Ponce (1996). These various cross sections were examined in light of present interpretations to assure that known geologic data and structural considerations were not ignored. The present interpretations are based solely upon the above-cited qualified data, and the earlier cross sections were used only as guidelines.

Subsurface borehole data from published and unpublished sources were also used as supporting data. These include data for boreholes C\#1, c\#2, and c\#3 (Geldon, 1993), borehole p\#1 in Carr and others (1986), those discussed by Gibson and others (1992), borehole WT-5 (R.W. Spengler, U.S. Geological Survey, written commun., 1994), and boreholes WT-14 and WT16 (R.W. Spengler, written commun., 1994; Muller and Kibler, 1985).

\section{REGIONAL SETTING}

Yucca Mountain, Nye County, Nevada, lies within the Walker Lane belt, which is a northwest-striking zone dominated by right-lateral wrench-zone tectonism (Stewart, 1980; Carr, 1984, 1990). The middle Miocene southwestern Nevada volcanic field (fig. 1) erupted from a series of calderas within the Walker Lane belt (Byers and others, 1976; Carr, 1984; Sawyer and others, 1994). The southwestern Nevada volcanic field is predominantly a series of silicic tuffs and lava flows that range in age from 8 to $15 \mathrm{Ma}$. One of the principal caldera complexes exposed in the southwestern Nevada volcanic field is the Timber Mountain-Oasis Valley caldera complex (Sawyer and others, 1994). The margin of the Timber Mountain-Oasis Valley caldera complex lies just north of the map area and was the source for many of the volcanic units exposed at Yucca Mountain. This caldera complex formed within an older north-trending Tertiary rift zone, which Carr (1986, 1990) defined as the Kawich-Greenwater rift. As such, Tertiary (pre-circa $13 \mathrm{Ma}$ ) extension provided the original tectonic framework for volcanism and subsequent tectonism at Yucca Mountain.

\section{STRATIGRAPHIC SETTING}

The study area is predominantly underlain by Miocene volcanic rocks of the Crater Flat, Paintbrush, and Timber Mountain Groups (Buesch and others, 1996). At Yucca Mountain, these are metaluminous extracaldera tuffs (Sawyer and others, 1994) made up of variably welded pyroclastic outflow sheets and tephra fallout deposits, with minor intercalated lava flows, ground surge, and reworked volcanic deposits.

The oldest units in the map area are ashflow tuffs of the quartz-rich Crater Flat Group. The Crater Flat Group is made up of the Tram Tuff, the 13.25-Ma Bullfrog Tuff, and the Prow Pass Tuff (Byers and others, 1976; Sawyer and others, 1994). The Tram Tuff does not crop out in the map area. The Bullfrog and Prow Pass Tuffs (units $b$ and $p$ ) crop out just west of Prow Pass in the northwesternmost part of the map area, but only the uppermost part of the Bullfrog Tuff is exposed in the map area. Its middle and lower parts are severed by the splay of the Windy Wash fault. Sawyer and Sargent (1989) suggested that the source for the Bullfrog was the Area 20 caldera, which is more than $20 \mathrm{~km}$ north of Prow Pass and lies along the northern margin of the Timber MountainOasis Valley caldera complex (fig. 1). Carr and others (1986) did not identify a source caldera for the Prow Pass Tuff, but suggested that its distribution is sufficiently limited that it may not have erupted from a caldera.

Regionally, the 13-Ma Wahmonie Formation overlies the Crater Flat Group. It crops out poorly ( $<3 \mathrm{~m}$ thick) and only on the northeastern and southeastern sides of Busted Butte (Broxton and others, 1993). As such, it was not mapped separately from the Quaternary deposits on this map. The Wahmonie Formation is made up of andesitic and dacitic rocks that erupted from the Wahmonie volcano (fig. 1) east of the map area (Poole and others, 1965; Broxton and others, 1989).

The 12.9-Ma Calico Hills Formation lies stratigraphically between the Crater Flat Group and the Paintbrush Group. This unit is composed of interbedded rhyolitic tuffs and lavas related to Crater Flat Group post-caldera volcanism (Sawyer and others, 1994). Dickerson and Drake (1998) proposed a source in the lower Fortymile Canyon area.

Rocks of the Paintbrush Group make up the vast majority of the bedrock exposures in the 
Yucca Mountain area. Buesch and others (1996) described the units of the Paintbrush Group and defined the members, zones, and subzones in both the Tiva Canyon and Topopah Spring Tuffs. The main units of the Paintbrush Group include (from oldest to youngest) the Topopah Spring Tuff, the Pah Canyon Tuff, the rhyolite of Zig Zag Hill, the rhyolite of Delirium Canyon, the rhyolite of Black Glass Canyon, the Yucca Mountain Tuff, the Tiva Canyon Tuff, the rhyolite of Vent Pass, and the rhyolite of Comb Peak. The quartz-poor 12.8-Ma Topopah Spring Tuff is made up of a lower crystal-poor rhyolitic member (Buesch and others, 1996) (units tpv, tpln, tpll, tpmn, tpul, and tp) and an upper crystal-rich quartz latite member (units trn, trv, and tr). The source caldera for the Topopah Spring remains undefined; however, Byers and others (1976) proposed the Claim Canyon caldera to the north of Yucca Mountain (fig. 1). Facies relations within the Topopah Spring Tuff around Yucca Wash and north of the map area are consistent with the Claim Canyon caldera as the most likely source.

The informal pre-Pah Canyon Tuff nonwelded bedded tuff (unit bt2) of Buesch and others (1996) lies above the nonwelded uppermost part of the Topopah Spring Tuff. Its distribution extends from the area of The Prow south throughout the entire map area. Where tuff bt2 is less than $2 \mathrm{~m}$ thick and the Pah Canyon Tuff is present as a mappable unit (unit pp), such as at The Prow, unit bt 2 is lumped with the overlying Pah Canyon Tuff. Where tuff bt2 is over $4 \mathrm{~m}$ thick and the Pah Canyon Tuff is not present as a mappable unit, such as in southern Fatigue Wash, unit bt2 is mapped separately. Where tuff bt 2 occurs in the interval of nonwelded, bedded tuff between the Topopah Spring and Tiva Canyon Tuffs, such as in the southern part of the map area, it is lumped with the other bedded tuffs as nonwelded bedded tuffs, undivided (unit bt).

Both the Pah Canyon Tuff and Yucca Mountain Tuff thicken from east to west in the northern part of the map area and pinch out toward the south in Fatigue Wash and Solitario Canyon. The pre-Yucca Mountain Tuff bedded tuff (unit bt3) is a thick, nonwelded tuff between the Pah Canyon and Yucca Mountain Tuffs in the northern part of the map area. Unit bt3 is as thick as $40 \mathrm{~m}$ in Yucca Wash, but thins to the south and pinches out approximately where the Pah Canyon and Yucca Mountain Tuffs pinch out. Southward from the pinch-out of these units, the nonwelded tuff (unit bt) between the Topopah Spring Tuff and the Tiva Canyon
Tuff is variously made up of pre-Pah Canyon Tuff bt2, pre-Yucca Mountain Tuff bt3, the distal part of the Pah Canyon and Yucca Mountain Tuffs, and the pre-Tiva Canyon Tuff bt4 of Moyer and others (1996). Locally, unit bt2 is the predominant tuff within unit bt.

The quartz-poor 12.7-Ma Tiva Canyon Tuff (Sawyer and others, 1994) overlies the nonwelded bedded units. The source of the Tiva Canyon Tuff was the Claim Canyon caldera (fig. 1) north of the map area (Byers and others, 1976). Like the Topopah Spring Tuff, the Tiva Canyon Tuff is made up of a lower crystal-poor rhyolitic member (Buesch and others, 1996) (units $c p v$ and $c p$ ) and an upper crystal-rich quartz latite member (unit $\mathrm{cr}$ ). It is overlain by pumiceous, pyroclastic-flow and fallout deposits (unit bt5) in southern Dune Wash as well as in northern Windy Wash.

Pyroclastic flow deposits and lava flows of the rhyolites of Delirium Canyon (unit dc), Black Glass Canyon (unit bg), Vent Pass (unit vp), and Comb Peak (units kt and kl) are exposed north of Yucca Wash in the northeastern part of the map area. The vent for the rhyolite of Comb Peak was defined by Dickerson and Drake (1995) to be at Comb Peak, just northeast of the map area. Facies and thickness relations within the rhyolite of Delirium Canyon suggest a source in upper Fortymile Canyon, also just north of the map area. The rhyolite of Black Glass Canyon is limited to Black Glass Canyon, and its source likely is located there as well. The source for the rhyolite of Vent Pass was probably near the northern boundary of the map area.

The quartz-rich 11.6-Ma Rainier Mesa Tuff, which is the oldest formation of the Timber Mountain Group, erupted from the Timber Mountain-Oasis Valley caldera complex (Byers and others, 1976). In the map area, the Rainier Mesa Tuff is made up of a lower nonwelded tuff (unit $\mathrm{mr}$ ) overlain by a partially to moderately welded rhyolitic ash-flow tuff (unit mrw). North of Yucca Wash, the rhyolite of Pinnacles Ridge (unit pr) forms a tuff cone and lava dome complex of limited areal extent.

Tertiary basaltic dikes (unit d) intrude Paintbrush Group rocks along the Solitario Canyon fault and along northwest-striking faults in the north-central part of the map area. Isotopic dating (K-Ar) of a basaltic dike that intrudes the Solitario Canyon fault at Little Prow yields an age of $10 \pm 0.4 \mathrm{Ma}$ (Carr and Parrish, 1985). This dike is itself brecciated along the fault, implying that movement along the Solitario Canyon Fault both predated and postdated the emplacement of the dike (Scott, 1990). 


\section{STRUCTURAL GEOLOGY}

The volcanic outflow sheets form a carapace of pyroclastic rocks around the southern and southeastern margins of the Claim Canyon caldera (fig. 1). The volcanic carapace was then disrupted by predominantly north-striking faults, along which the volcanic units were tilted into east-dipping structural blocks at Yucca Mountain.

Faults at Yucca Mountain can be classified as block-bounding faults, relay (and associated) structures, strike-slip faults, or intrablock structures. The block-bounding faults generally strike north, are spaced 1-4 km apart (fig. 3), and have throws of as much as hundreds of meters. Subordinate amounts of strike-slip motion are common. In some places, Quaternary to Recent offset has been documented on these faults (see Simonds and others, 1995). Relay structures link the block-bounding faults. These can be either large-scale features, commonly forming fault zones or systems with greater than $100 \mathrm{~m}$ of aggregate offset, or they can be small-scale features made up of one or more faults that interconnect with the block-bounding faults and have cumulative offset on the order of tens of meters. Internally, the fault zones can be made up of horst and graben structures, with an overall net displacement of units across the zone. The large strike-slip faults are restricted to the north-central part of the map area. Intrablock structures are relatively minor faults that lie entirely within the structural blocks defined by block-bounding faults (fig. 3). The intrablock faults typically have mapped lengths of less than $1 \mathrm{~km}$, but are as long as $7 \mathrm{~km}$, as noted in the combined length of the Ghost Dance and Abandoned Wash faults.

\section{DESCRIPTION OF BLOCK-BOUNDING FAULTS}

Deformation associated with the blockbounding faults at Yucca Mountain affects several major repository issues such as the volume and quality of rock available for underground construction of the potential repository, the delineation of hydrologic flow paths, and seismic hazard assessments. The present map depicts the distribution of structures associated with the block-bounding faults, thus providing critical data needed to resolve these issues. Because of erosion and partial burial of hanging-wall blocks adjacent to the main fault trace, depiction of structures in footwall blocks is generally more detailed than in the hanging-wall counterparts. From west to east, the block-bounding faults include (fig. 3) the Northern Windy Wash, Fatigue Wash, Solitario Canyon, and Iron Ridge faults, several unnamed faults between the Iron Ridge fault and Dune Wash, and the East Ridge, Dune Wash, northern part of the Bow Ridge, Midway Valley, and Paintbrush Canyon faults. These north- and northwest-trending, blockbounding faults are often linked kinematically by northwest-trending relay faults and associated structures, which act to distribute displacement across several of the faults. Mineral lineations and mullions developed on fault scarps indicate that a subordinate component of sinistral slip was commonly associated with the blockbounding faults (Scott and Bonk, 1984; O'Neill and others, 1992; Simonds and others, 1995; Day and others, 1996; Day and others, 1998).

The block-bounding faults generally dip west with variable dips ranging from relatively shallow $\left(45^{\circ}-50^{\circ}\right)$ to steep $\left(75^{\circ}-85^{\circ}\right)$. The amount of secondary faulting preserved in the footwall is higher in areas along traces of the fault zones that have shallower dips. The subordinate leftlateral component of motion within some of the zones set up releasing and restraining bends locally along the trace of the main fault zones. Restraining bends are along segments of the block-bounding faults that strike north-northeast. One such area is preserved in the hanging wall of the Bow Ridge fault near the south portal of the ESF (Exploratory Studies Facility). In this area the Bow Ridge fault strikes north-northeast. Farther to the south the strike of the fault changes to the northwest at the saddle between Bow and Boundary Ridges (fig. 2). An east-dipping reverse fault in the hanging wall, intersected in the ESF, formed due to local compression in this area of the restraining bend on Bow Ridge fault.

Previous workers recognized west-dipping strata that form coherent structural panels within some of the hanging walls of the blockbounding fault zones (Scott and Bonk, 1984; Scott, 1990; Potter and others, 1996). Such west-dipping panels are preserved in the hanging wall of the Solitario Canyon fault (north of Plug Hill), the Iron Ridge fault (north of borehole WT11), and the Northern Windy Wash fault (southwest of Prow Pass). The west-dipping panels are bounded on their western side (west of the block-bounding fault) by steeply dipping faults that splay off of the west-dipping block-bounding faults at depth.

\section{DESCRIPTION OF RELAY STRUCTURES}

Relay structures kinematically link the blockbounding faults and form an integral part of the 

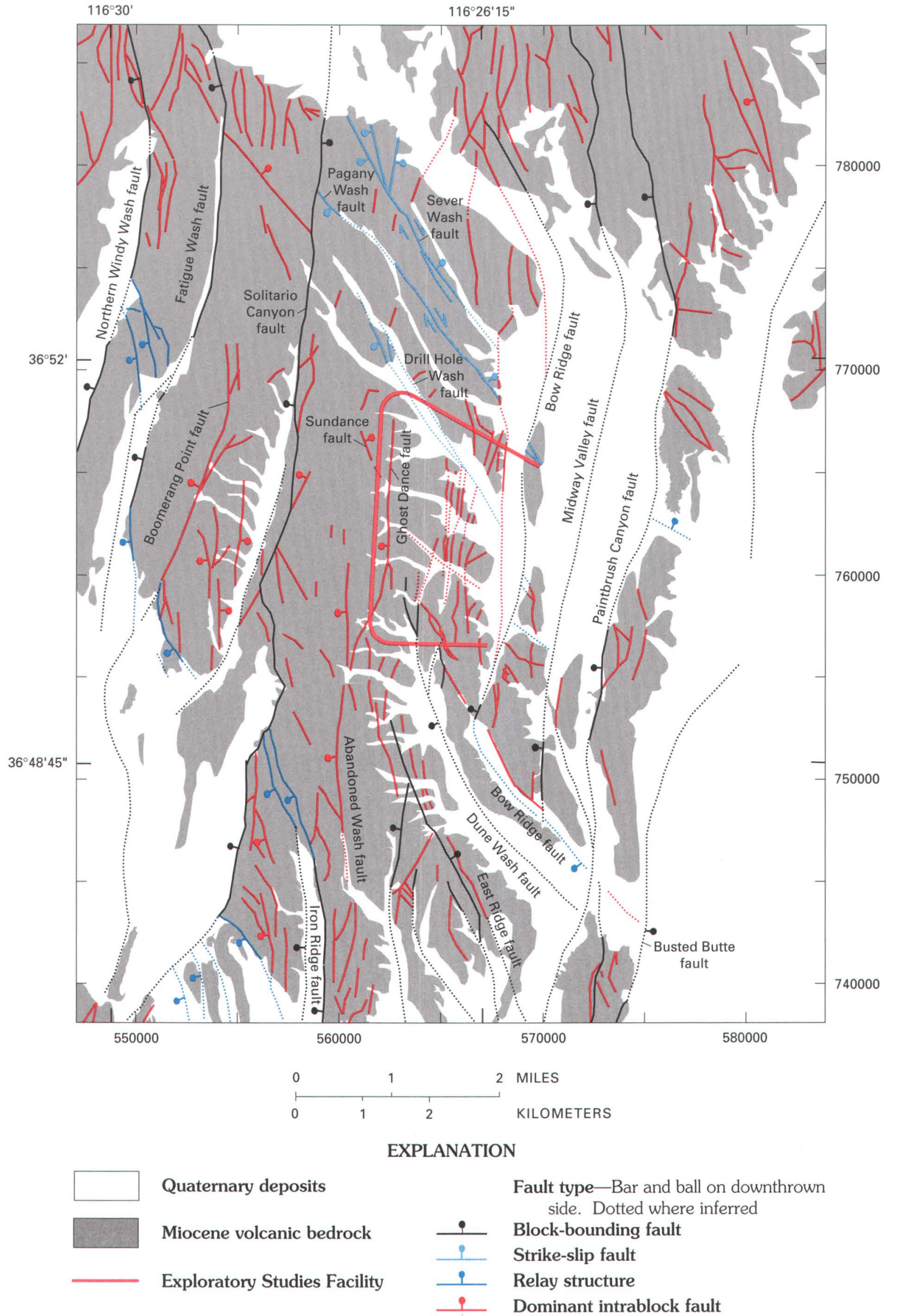

Fault type - Bar and ball on downthrown side. Dotted where inferred

Block-bounding fault

Strike-slip fault

Relay structure

Dominant intrablock fault

Figure 3. Distribution of fault types in the map area. 
structural framework of Yucca Mountain. Relay structures range in size from large zones of complexly anastomosing normal faults that rival the total displacement and rock-mass damage of many block-bounding faults, to simple small faults and grabens that rival intrablock faults. One such large relay structure cuts through West Ridge (figs. 2 and 3), connecting the Northern Windy Wash and Fatigue Wash faults. It consists of a system of predominantly southwestdipping normal faults with down-to-the-southwest displacement coupled with a subordinate number of nearly vertical, northeast-side-down normal faults. Moderate-scale (50-200 m wide) horsts and grabens occur within the relay zone. The aggregate displacement across the zone is approximately $60 \mathrm{~m}$, down to the southwest.

Two other relay structures effectively cut the southern end of Jet Ridge. A northweststriking, southwest-side-down normal fault exposed directly above the colluvial apron along the southwestern end of Jet Ridge (west of the Boomerang Point fault) drops the crystal-rich member of the Topopah Spring Tuff (unit trn) about $20 \mathrm{~m}$. Although the fault projects beneath the alluvial cover, it is inferred to connect the Fatigue Wash and Boomerang Point faults. Another relay fault is exposed east of the southern extent of the Boomerang Point fault. At the southern terminus of Jet Ridge, the middle and lower parts of the crystal-poor member of the Tiva Canyon Tuff (unit $c p$ ) are downthrown along a north-northwest-striking normal fault against the top of the Topopah Spring Tuff. This west-dipping, down-to-the-west fault has at least $100 \mathrm{~m}$ of displacement and projects to the south along the foot of Boomerang Point. A splay of this fault strikes to the southeast just west of borehole WT-7 and has over $70 \mathrm{~m}$ of west-side-down displacement. A thin sliver of the crystal-rich member of the Topopah Spring Tuff (unit trn) forms a horst block within the normal-fault zone. Therefore, this part of the northeastern margin of Crater Flat is defined by northwest-striking, southwest-side-down relay faults, both exposed and buried.

Another important relay structure slices across Yucca Crest southwest of borehole G-3. Two dominant northwest-striking, southwestdipping faults cut the Paintbrush Group rocks and connect the Solitario Canyon fault with the Iron Ridge fault and associated faults. In the footwall of the Solitario Canyon fault, the easternmost of these two faults places the middle part of the Tiva Canyon Tuff (unit $\mathrm{cp}$ ) down against the middle nonlithophysal zone of the Topopah Spring Tuff (unit tpmn). Total southwest-side-down displacement across these two faults is more than $120 \mathrm{~m}$ along the major saddle of Yucca Crest, placing the top of the Tiva (on the hanging wall) against its base (on the footwall). Numerous normal faults crop out just east of the Iron Ridge fault north of borehole WT-11. These gently west-dipping faults formed in the footwall of the Iron Ridge fault where slices of the footwall were downdropped into the main fault zone along spoonshaped faults.

The strike of the Bow Ridge fault changes abruptly at the saddle between Bow and Boundary Ridges from north-northeast on the northern side of the saddle to a northwestern strike south of the saddle. The southern part of the fault, which strikes into the Paintbrush Canyon fault north of Busted Butte, can be thought of as a relay connecting the northern part of the Bow Ridge fault with the Paintbrush Canyon fault.

Small relay structures also connect some of the block-bounding faults. Examples are exposed on Exile Hill, just north of the north portal of the ESF. Four northwest-striking, down-to-thenortheast normal faults terminate against the Bow Ridge fault on their northwestern ends and against the east-side-down Exile Hill fault at their southeastern ends. Although the aggregate displacement across these faults is minimal (less than $20 \mathrm{~m}$ ), the intervening rock mass is highly brecciated. Another series of small northweststriking relay faults is exposed on the northern part of Bow Ridge, linking the Bow Ridge and Midway Valley faults. One of these faults cuts through the c-hole complex (boreholes c\#1, c\#2, and $\mathrm{c \# 3}$ ). The northern tip of Bow Ridge also hosts several small northwest-striking faults. A parallel-striking fault $350 \mathrm{~m}$ to the south of the c-hole complex has only about 10-15 $\mathrm{m}$ of down-to-the-southwest displacement.

\section{DESCRIPTION OF THE PROMINENT NORTHWEST-STRIKING STRIKE-SLIP FAULTS}

Three main northwest-striking strike-slip faults are exposed in the northern part of the map area: the Sever Wash, Pagany Wash, and Drill Hole Wash faults. They have been described by Scott and others (1984), Simonds and others (1995), and Day and others (1998). Kinematic indicators preserved along the scarps of the Sever Wash and Pagany Wash faults indicate that the latest motion was strike slip. Preserved along the Sever Wash fault are zones of silicified breccia, subhorizontal slickensides, and subhorizontal mullion structures. Along the trace of the Pagany Wash fault, Reidel shears 
are well developed in the welded part of the Yucca Mountain Tuff in Pagany Wash (Simonds and others, 1995). The Reidel shears form an acute angle (about $30^{\circ}$ ) measured clockwise from the main fault plane, indicating dextral motion on the fault plane during formation of the shears. Another feature of both faults is the apparent reversal of the vertical component of offset along their traces. Along their northwestern part the faults show down-to-the-southwest displacement, which changes to down-to-thenortheast along their southeastern part.

The Drill Hole Wash fault is buried beneath Quaternary alluvial deposits in the floor of Drill Hole Wash. The main trace of the fault is intersected in the subsurface in borehole a\# 4 (Spengler and Rosenbaum, 1980) and in the ESF (Steven C. Beason, U.S. Bureau of Reclamation, oral commun., 1995). The fault is exposed at the surface on Tonsil Ridge northwest of borehole $\mathrm{H}-1$. Here the fault strikes N. $30^{\circ} \mathrm{W}$., dips steeply $\left(80^{\circ}-85^{\circ}\right)$ to the southwest, and has a cumulative throw of approximately $15 \mathrm{~m}$ down to the southwest. This fault projects into the subsurface into a fault zone exposed in the ESF, which has an apparent offset of least $1.2 \mathrm{~m}$ (down-to-the-southwest). Exposures in the ESF reveal subhorizontal slickensides with a dextral sense of slip. The variability in relative vertical offset along the fault trace in the 400-m distance between Tonsil Ridge and the ESF $(15 \mathrm{~m}$ at the surface compared to $1.2 \mathrm{~m}$ in the ESF) and orientation $\left(\mathrm{N} .30^{\circ} \mathrm{W}\right.$. versus $\mathrm{N} .10^{\circ} \mathrm{W}$., respectively) is similar to that observed on intrablock faults throughout the map area.

Scott and Bonk (1984) inferred a northwest-striking fault beneath Yucca Wash, based on their interpretation of aeromagnetic data. The wash is a prominent geomorphic erosional feature beneath which it is reasonable to infer a fault. Significant changes in volcanic facies occur across and north of Yucca Wash, but those facies changes do not require the presence of a fault. Dickerson (1996) observed that several north-striking block-bounding faults can be traced continuously across Yucca Wash in the subsurface using detailed ground magnetic data of Ponce and Langenheim (1994). Therefore, there is no direct or indirect evidence for a significant fault beneath Yucca Wash.

\section{DESCRIPTION OF INTRABLOCK STRUCTURES}

Intrablock faults by definition are within the intervening rock mass between the block-bounding faults. In some cases, intrablock faults are expressions of hanging-wall or footwall deformation that affects the block within a few hundred meters of the block-bounding faults. Other intrablock faults, such as the northwesttrending narrow grabens seen on Boundary Ridge, are present in the central and southern parts of the map area. The grabens are local expressions of regional Tertiary extension and form minor dilation zones in the structural blocks. Intrablock and block-bounding faults share common geometric elements. Intrablock faults, such as the Ghost Dance, Abandoned Wash, and Busted Butte faults, are marked by zones that widen upward near the surface, becoming frameworks of upward-splaying faults (Day and others, 1998). This pattern is shared by the block-bounding faults.

Intrablock faults in the central and southern parts of the map area include the Boomerang Point, Ghost Dance, Abandoned Wash, Sundance, and Busted Butte faults, as well as unnamed faults in the block west of Dune Wash on East Ridge. The Boomerang Point fault bisects the Jet Ridge block (figs. 3 and 4). Down-tothe-west displacement along this fault increases southward to more than $120 \mathrm{~m}$ over a strike length of approximately $4 \mathrm{~km}$. Rocks between the Boomerang Point fault and the Fatigue Wash fault contain very few faults-making it one of the least deformed parts in the Yucca Mountain area. The number of faults in the block east of the Boomerang Point fault is greater due to the increase in dip associated with hanging-wall deformation of the Solitario Canyon fault.

The Ghost Dance fault is the main intrablock fault within the central part of the potential repository area. It is a north-striking normal fault zone that dips steeply west with down-tothe-west displacement. The displacement, amount of brecciation, and number of associated splays vary considerably along its trace (Spengler and others, 1993; Day and others, 1998). The Abandoned Wash fault is interpreted to connect with the Ghost Dance fault in the area of Ghost Dance Wash. From this area south, the Abandoned Wash fault extends another 3.8 $\mathrm{km}$. It terminates in the wash south of borehole G-3. As such, the 7-km-long Ghost DanceAbandoned Wash fault is entirely an intrablock fault with no surface connection to any known block-bounding fault. Any connection at depth with block-bounding faults is inferential.

The Sundance fault zone is exposed south of Drill Hole Wash between Live and Dead Yucca Ridges. Spengler and others (1994) first identified the Sundance fault as a wide zone of minor northwest-striking faults that commonly show down-to-the-northeast displacement. 
Subsequent detailed mapping by Potter and Dickerson (in Day and others, 1998) showed that the fault zone is about $750 \mathrm{~m}$ long, extends from Dead Yucca Ridge southeastward to Live Yucca Ridge, and has a maximum cumulative down-to-the-northeast displacement of $11 \mathrm{~m}$. In the ESF, the Sundance is a series of discontinuous narrow fault zones with minor amounts of vertical offset.

Numerous intrablock faults are present in the southern part of the map area. One of the most prominent slices through Busted Butte. This west-side-down normal fault has one of the greatest vertical exposures (over $250 \mathrm{~m}$ ) of any intrablock fault in the map area. The upwardbranching nature of faults described by Day and others (1998) for faults in the central block area is well displayed along the fault that splits Busted Butte. The lowest exposures of the fault at the base of Busted Butte form a zone of intense brecciation approximately $3 \mathrm{~m}$ wide. The fault branches upward into several splays forming an approximately $110-\mathrm{m}$-wide zone. The western splay of the fault zone is actually an east-dipping reverse fault. The gently east-dipping crystalrich Tiva Canyon Tuff (unit $\mathrm{cr}$ ) in the footwall (west of fault splay) is overlain by a fault sliver of vertically dipping older crystal-poor Tiva (unit $c p$ ) in the hanging wall (east of fault splay).

Dips of the intrablock faults are generally steeper than those of the block-bounding faults. The intrablock dips shown on the cross sections were derived from the mapped trace of the fault intersection with topography and range generally from $75^{\circ}$ to vertical. Measured scarps along the block-bounding faults vary, but dips generally are between $60^{\circ}$ and $75^{\circ}$ to the west. If all of the intrablock faults formed prior to the rotation of the beds into their generally eastward dip, then the intrablock faults would have formed originally as reverse faults. Kinematically, this would be unlikely in that deformation of the Tertiary tuffs throughout the map area was extensional. Therefore, the intrablock faults probably formed during and after tilting of the beds on the block-bounding faults.

\section{STRUCTURAL DOMAINS}

The map area can be divided into ten structural domains (fig. 4), each characterized by a distinctive structural style. These structural domains all lie within the more regional Crater Flat tectonic domain as defined by Fridrich (in press). The term "structural domain" is used here to denote an area characterized by a particular structural style that is distinct from that of adjacent areas. The distinctive structural patterns that characterize individual domains include both the geometry and intensity of faulting as well as the magnitude and direction of stratal dips. These domains reflect protracted deformation and record an integrated structural response through time. In general, structural domains can be identified at any scale; those defined herein are appropriate for this $1: 24,000$ map scale. In this context, the structural domains as defined below are typically an aggregate of distinct structural blocks that share common intrablock fault characteristics and stratal dips. They are briefly described below, as a summary of the overall structural geology of the map area.

\section{CENTRAL YUCCA MOUNTAIN DOMAIN}

The largest domain is the Central Yucca Mountain domain, which comprises three easttilted blocks bounded by west-dipping blockbounding faults. From west to east, these blocks include (1) the West Ridge block, bounded on the west by the Northern Windy Wash fault and on the east by the Fatigue Wash fault; (2) the Jet Ridge block, bounded on the west by the Fatigue Wash fault and on the east by the Solitario Canyon fault; and (3) the central block, bounded on the west by the Solitario Canyon fault and on the east by the Bow Ridge fault. The West Ridge block is about $1 \mathrm{~km}$ wide and 5 $\mathrm{km}$ long, the Jet Ridge block is about $2 \mathrm{~km}$ wide and $7 \mathrm{~km}$ long, and the central block is about 4 $\mathrm{km}$ wide and $7 \mathrm{~km}$ long. In each of these blocks, stratal dips for the Paintbrush Group ash-flow tuffs are typically $5^{\circ}-10^{\circ}$ to the east, steepening along the eastern edges of the blocks in the hanging walls of block-bounding faults to values as large as $20^{\circ}$. Intrablock faults, such as the north-striking Ghost Dance and Abandoned Wash faults in the central block and the Boomerang Point fault in the Jet Ridge block, are locally prominent (see "Structural geology" section). The central block and, to a much lesser extent, the Jet Ridge block contain a complex zone of intrablock faulting along the eastern edge (Scott and Bonk, 1984; Day and others, 1998). This block-margin faulting, accompanied by steepening of stratal dips, reflects the stratal rotation and internal deformation produced in the hanging wall of a complex block-bounding fault zone (Scott, 1990; Day and others, 1998).

The northern edge of the Central Yucca Mountain domain is more highly deformed than the central and southern parts. For example, near The Prow (figs. 2 and 4) the frequency and intensity of intrablock faulting increase. Along the northwest-trending edge of Yucca Mountain 


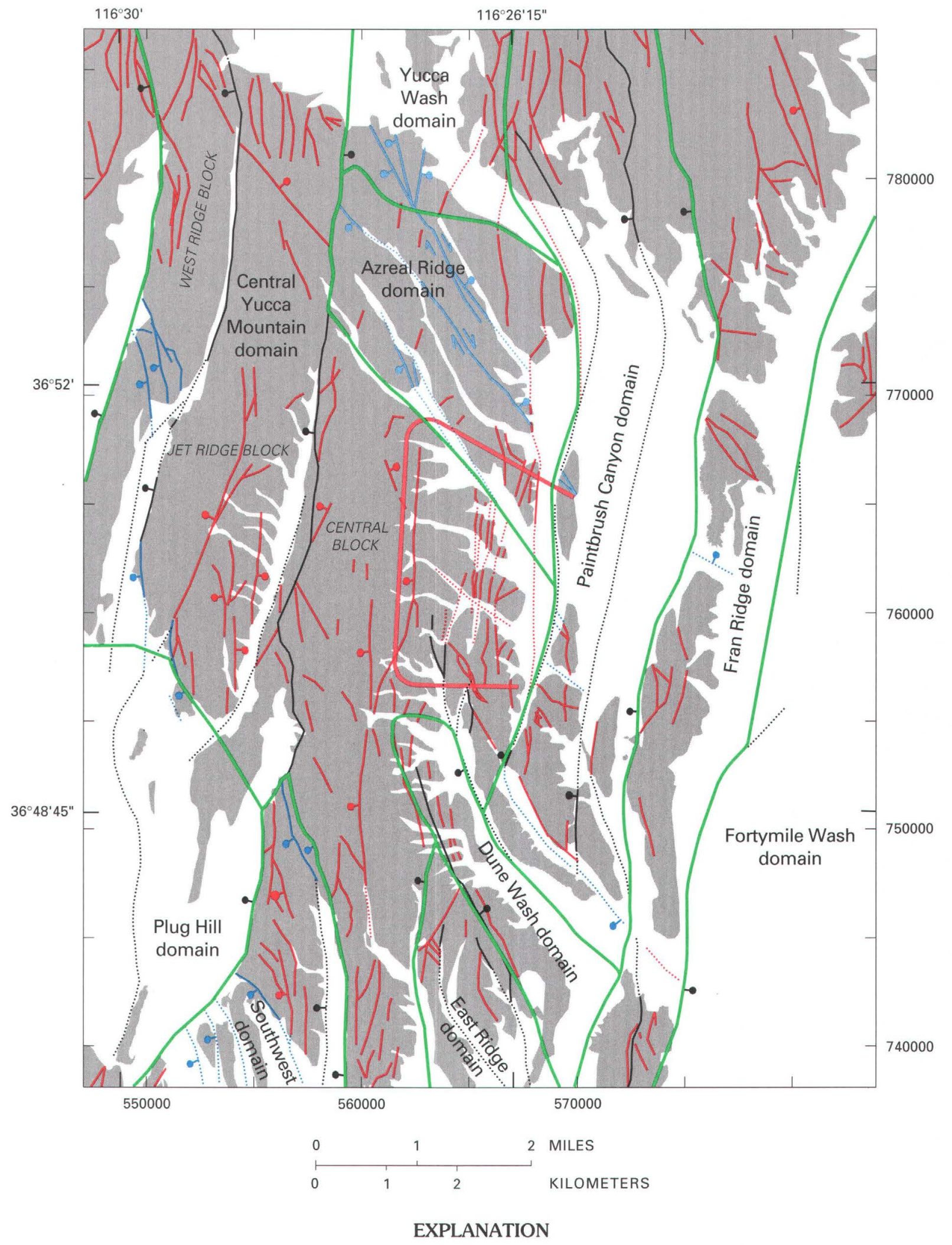

Quaternary deposits

\begin{tabular}{|l}
$\square$ \\
\hline
\end{tabular} Miocene volcanic bedrock

- Exploratory Studies Facility

Structural domain boundary

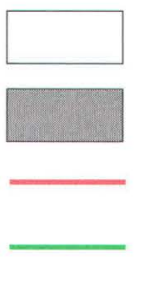

EXLANATION

Figure 4. Distribution of structural domains defined for the map area. 
between The Prow and Castellated Ridge, southeast-dipping Paintbrush Group strata are cut by a series of north- to north-northweststriking normal faults that range in offset from 2 to $70 \mathrm{~m}$; east-side-down and west-side-down displacements are about equally divided (see cross section $A-A^{\prime}$ ). Through the northwestern corner of the map area and to the north of the map area, the Northern Windy Wash fault maintains its character as a complex, west-side-down block-bounding fault. The Fatigue Wash fault continues through the area of The Prow as a west-side-down blockbounding fault.

\section{AZREAL RIDGE DOMAIN}

The Azreal Ridge domain lies between Drill Hole Wash and Yucca Wash, northeast of the Central Yucca Mountain domain (fig. 4). The intensity of faulting in this domain is relatively low compared with the Central Yucca Mountain, Dune Wash, or Southwest domains to the south (see below). Faulting within the domain is dominated by the three strike-slip faults previously discussed (Sever Wash, Pagany Wash, and Drill Hole Wash faults). The intrablock faults are minor, north-trending normal faults with limited brecciation. Strata dip gently southeast $\left(4^{\circ}-9^{\circ}\right)$ in the main part of the domain. Along the eastern edge of the domain in the hanging wall of the Bow Ridge fault, deformation intensifies as recorded by the increase of the stratal dips (as much as $13^{\circ}$ ) and relative intensity of faulting.

The transition from the northern margin of the central block to the Azreal Ridge domain (fig. 4 ) is marked by a decrease in the magnitude of east-west extension, manifested in a fundamental change in the nature of the two blockbounding faults. West-side-down displacements along the Solitario Canyon and Bow Ridge faults diminish to zero at hinge points within northern Yucca Mountain. North of these hinge points, east-side-down displacements are mapped along these faults. For the Solitario Canyon fault, the hinge point is in Teacup Wash, and for the Bow Ridge fault, the hinge point lies beneath Quaternary alluvium east of Isolated Ridge. The Azreal Ridge domain occupies the little-extended area bounded by the segments of these two faults that have undergone minimal displacements near the hinge points.

In addition to the decreased magnitude of extension, the Azreal Ridge domain is characterized by a change in the direction of stratal dips and a change in intrablock faulting style. In contrast to the easterly dips predominant in the
Central Yucca Mountain domain, the Azreal Ridge domain consists of gently southeastdipping Paintbrush Group strata. Because the main ridges and washes at Yucca Mountain have generally developed parallel to the dip of the Paintbrush Group welded tuffs, this southeast dip is expressed geomorphically as a strong northwest-trending topographic grain. The southeast-dipping strata in the Azreal Ridge domain actually form one limb of a broad southeast-plunging syncline, and the other limb is defined by the east-dipping strata of the central block. The axis of this syncline lies beneath Drill Hole Wash.

\section{YUCCA WASH DOMAIN}

North of the Azreal Ridge domain, the Yucca Wash domain records a northward increase in the magnitude of east-west extension, accommodated by displacements along several north- to northwest-striking intrablock and strike-slip faults. These include several prominent splays of the Sever Wash fault just south of Yucca Wash, along which the amount of stratigraphic displacement increases markedly to the north. This structural style is similar to that in the adjacent part of the Central Yucca Mountain domain near The Prow, as previously discussed, and it continues on the north side of Yucca Wash within the Yucca Wash domain (fig. 4). Bedrock dips within the Yucca Wash domain, as preserved in the Paintbrush Group, are steeper $\left(14^{\circ}-28^{\circ}\right)$ and more easterly than in the adjoining Central Yucca Mountain or Azreal Ridge domains.

\section{PAINTBRUSH CANYON DOMAIN}

The Paintbrush Canyon domain is characterized by closely spaced faults that divide this domain into a series of long, narrow, northtrending, east-dipping blocks ranging from 0.6 to $1 \mathrm{~km}$ in width (fig. 4). The domain is bounded on the east and west by the Paintbrush Canyon and Bow Ridge faults, respectively, and it includes prominent north-striking faults such as the Black Glass Canyon, Midway Valley, and Exile Hill faults. The northern part of the domain is well exposed north of Yucca Wash, whereas the bedrock in the central part of the domain is obscured by Quaternary deposits in the Midway Valley area. The bedrock in the southern part of the domain resurfaces on Bow Ridge and San Juan Hill to the east (just west of the Paintbrush Canyon fault; figs. 2 and 4). Where exposed, the Paintbrush Group generally strikes northward, but dips more steeply (as 
much as $46^{\circ}$ ) to the east than in the adjacent Central Yucca Mountain domain.

In the northern part of the domain, fault blocks are juxtaposed along down-to-the-west normal faults with extensive deformation in their hanging walls. This hanging-wall deformation includes graben development, numerous splays, pull-apart structures, and wide, internally sheared, massively brecciated, multi-plane main fault zones. Geophysical interpretations strongly suggest that fault blocks buried beneath surficial deposits in Midway Valley define a horst-andgraben pattern (Ponce, 1993; Ponce and others, 1993). Exile Hill, for example, represents a horst block in this domain. Another buried horst occurs to the east beneath the center of Midway Valley; these horsts are $0.3-0.7 \mathrm{~km}$ wide.

The continuity of north-trending faults from north of Yucca Wash southward through Midway Valley is one of the unifying characteristics of the Paintbrush Canyon domain. Geophysical and geologic data indicate that the main faults exposed north of Yucca Wash continue southward beneath Quaternary deposits to the southern part of Midway Valley (Dickerson and Drake, 1998). This observation argues strongly against the presence of the Yucca Wash fault as a major structure.

Along the east edge of the Paintbrush Canyon domain, the magnitude and complexity of the Paintbrush Canyon fault increase to the south. Over $200 \mathrm{~m}$ of displacement is recorded along this fault in upper Paintbrush Canyon (Dickerson and Spengler, 1994; Dickerson and Drake, 1998), and over $300 \mathrm{~m}$ of displacement near Fran Ridge. Beneath southeastern Midway Valley, buried northeast-striking splays are inferred to have propagated from the main trace of the Paintbrush Canyon fault (Ponce, 1993). The horst-and-graben pattern that characterizes most of Midway Valley is cut off by (or merges into) these splays. At the southern end of the Paintbrush Canyon domain the Paintbrush Canyon fault merges with the Dune Wash and Bow Ridge faults (fig. 3); the Paintbrush Canyon fault system collects the aggregate displacement of all of these faults. Unfortunately, the area of intersection of these faults, surely one of the most deformed and structurally complex areas of Yucca Mountain, is concealed beneath surficial deposits northwest of Busted Butte.

\section{FRAN RIDGE DOMAIN}

East of the Paintbrush Canyon domain, the Fran Ridge domain is a north-trending, largely intact block between the Paintbrush Canyon fault and Fortymile Wash. It includes (from north to south): Comb Peak (just off the northeastern part of the map area) and the bedrock tract to its south, Alice Point, Fran Ridge, and Busted Butte. In the northern part of the domain the Paintbrush Group and older rocks strike northward and dip steeply $17^{\circ}-27^{\circ}$ to the east. In the central part of the domain on Fran Ridge, rocks of equivalent age strike northward and dip more gently to the east $\left(5^{\circ}-17^{\circ}\right)$. To the south on Busted Butte, the bedrock dips are gentle to the east $\left(5^{\circ}-10^{\circ}\right)$. The Fran Ridge domain is characterized by less internal deformation than that found in the Paintbrush Canyon domain. Smaller faults, which splay eastward off the northern extent of the Paintbrush Canyon fault, indicate a greater amount of footwall deformation for the Paintbrush Canyon fault than is demonstrated for the exposed faults in the Paintbrush Canyon domain. Although the internal deformation is minor in most of the Fran Ridge domain, a few intrablock faults have significant amounts of offset, such as the Busted Butte fault $(75 \mathrm{~m})$ and the fault south of Comb Peak $(130 \mathrm{~m})$. Additionally, the Fran Ridge domain is structurally higher than the adjacent Paintbrush Canyon and Fortymile Wash domains. Gaps between the topographic highs within the Fran Ridge domain are occupied by buried down-to-the-northeast faults that lie between Busted Butte and Fran Ridge, and between Fran Ridge and Alice Point.

\section{FORTYMILE WASH DOMAIN}

Geologic relations within the Fortymile Wash domain are poorly understood because the bedrock geology of this domain largely is concealed by the surficial deposits of Jackass Flats. Furthermore, the prevailing easterly dip of the Paintbrush Group strata in the Fran Ridge domain strongly suggests that a major westside-down normal fault may lie east of Fortymile Wash beneath the western part of Jackass Flats. The northern part of the Fortymile Wash domain consists of the extensively faulted rocks east of Fortymile Canyon. There is no preferred orientation for faults in this area, as faults strike east-west, north-south, northeastsouthwest, and southeast-northwest. It is not known to what extent this random fault pattern characterizes other parts of the Fortymile Wash domain where bedrock is not exposed.

\section{PLUG HILL DOMAIN}

The Plug Hill domain lies in the eastern margin of Crater Flat on the southwest side of the map area. It contains low-lying hills of Tiva 
Canyon Tuff as well as exposures of the Rainier Mesa Tuff on Plug Hill itself. The domain is rimmed by normal faults that drop units of the Paintbrush Group into Crater Flat. The northern margin of the domain is delineated by the relay structures on the southern tip of Jet Ridge, and the eastern and southern margin by the Solitario Canyon fault, which curves from a north strike to a more northeasterly strike. Although the bedrock is poorly exposed, where present it is made up of highly faulted, eastwarddipping blocks. Plug Hill is made up of Tiva Canyon Tuff overlain by nonwelded and welded units of the Rainier Mesa Tuff. The amount of faulting within the Rainier Mesa Tuff is hard to detect because it lacks internal marker horizons and is poorly exposed. However, Day and others (1998) did map faulted Paintbrush Group rocks caught in the hanging-wall deformation of the Solitario Canyon fault that are overlain by Rainier Mesa Tuff, suggesting that eruption of the Rainier Mesa postdated some of the postPaintbrush Group deformation on the hanging wall of the Solitario Canyon fault. This relation is unique to the Plug Hill area. Here, as elsewhere, the Rainier Mesa Tuff is preserved only on the hanging wall of the block-bounding faults. Implications of the distribution of the Rainier Mesa Tuff are discussed in the "Discussion on the variation and timing of tectonism at Yucca Mountain" section.

\section{SOUTHWEST DOMAIN}

In the Southwest domain, which lies between Double Notch Ridge and Crater Flat (figs. 2 and 4), north-trending, block-bounding faults are linked kinematically by northwest-trending relay faults and associated structures. An excellent example is the complex northwest-striking relay zone between the Solitario Canyon and Iron Ridge faults near the north end of the Southwest domain. Several other relay faults splay off the Solitario Canyon fault in the southernmost part of the map area in the Southwest domain, transferring strain from the main trace of the Solitario Canyon fault. The vertical component of offset on the Solitario Canyon fault (east of Plug Hill) is over $400 \mathrm{~m}$. However, at its southernmost trace (at the southern margin of the map area) the offset is only on the order of $60 \mathrm{~m}$. The aggregate vertical displacement taken up by the intervening five relay faults is over $60 \mathrm{~m}$ each, accounting for the missing vertical component of displacement on the Solitario Canyon fault.

Northwest-striking narrow grabens are commonly associated with relay faults, here and elsewhere in the southern part of Yucca Mountain. The block-bounding fault systems in this domain are west-dipping, upward-widening arrays, with westerly dips ranging from relatively shallow $\left(45^{\circ}-50^{\circ}\right)$ to steep $\left(75^{\circ}-85^{\circ}\right)$. As the upward-widening fault zones attain shallower dips, the amount of secondary faulting preserved in the footwall of the block-bounding fault system increases dramatically. In addition, fracturing of the footwall increases near the major relay faults.

\section{EAST RIDGE DOMAIN}

The East Ridge domain lies to the west of the Dune Wash domain (fig. 4). It is bounded on the west by the unnamed block-bounding fault west of borehole WT-12 and the down-to-theeast block-bounding faults just east of East Ridge on the western edge of the Dune Wash graben. This domain differs from the adjacent Central Yucca Mountain domain in that the amount of intrablock faulting is more intense, recording a greater amount of extensional deformation. The strata strike north-northeast and dip generally $15^{\circ}-20^{\circ}$ to the east, more steeply than is observed in the Central Yucca Mountain domain. This domain also has numerous east-side-down faults, which splay off the block-bounding fault along the western edge of the Dune Wash graben.

\section{DUNE WASH DOMAIN}

The Dune Wash domain (fig. 4) is defined by the northwest-trending Dune Wash graben, which is bounded on its east side by the downto-the-west block-bounding Dune Wash fault and on its southeast margin by the Paintbrush Canyon fault. Its western margin is bounded by the down-to-the-east block-bounding East Ridge fault zone (fig. 3), which has at least $120 \mathrm{~m}$ of down-to-the-east displacement. This down-tothe-east fault zone is approximately $100 \mathrm{~m}$ wide, contains tectonically brecciated and juxtaposed units of the Topopah Spring Tuff (unit tx), and in places exhibits higher degrees of oxidation, silicification, and alteration compared with other block-bounding faults. This fault zone splays to the south-southwest into several faults with down-to-the-east displacement. The splays each have over $30 \mathrm{~m}$ of displacement. Within the interior of the graben are numerous, smaller horst-and-graben blocks whose strata dip predominantly to the east. The structure of the interior of the graben is highly complex with numerous discontinuous, steeply dipping faults. The Dune Wash domain is one of the areas 
depicted by figure 6 of Scott (1990) as a broad imbricate fault zone; although it is intensely faulted, it is not characterized by consistent west-side-down offset along the array of faults, as Scott (1990) implied by his definition and use of the term "imbricate fault zone."

In the northern end of the Dune Wash graben (southwest of borehole WT-1), the western bounding fault of the graben steps about $200 \mathrm{~m}$ to the west and displacement decreases; this fault places the crystal-rich member of the Tiva Canyon Tuff (unit $\mathrm{cr}$ ) down against the pre-Tiva Canyon, post-Topopah Spring nonwelded bedded tuffs (unit bt). The displacement on individual faults within the graben decreases to the north, but the overall horst-andgraben pattern is maintained. At the northern end of the graben, just south of the mouth of Abandoned Wash, the faulting resembles the closely spaced faulting that characterizes blockmargin deformation in the central block to the north. The southern end of the Dune Wash domain, which is buried beneath Quaternary deposits southwest of Busted Butte, seems to terminate against the down-to-the-west Paintbrush Canyon fault.

\section{DISCUSSION ON THE VARIATION AND TIMING OF TECTONISM AT YUCCA MOUNTAIN}

The variation in deformation from a lessextended northern part of Yucca Mountain to a more-extended southern part is generally expressed on geologic maps by an increase in throw to the south along the block-bounding faults. In intrablock areas, the transition is expressed by the appearance of numerous closely spaced minor faults that coalesce and gain displacement to the south. These patterns are apparent in the northern part of Dune Wash, particularly near the mouth of Abandoned Wash. Southward-increasing east-west extension is also recorded by the southward splaying of the Solitario Canyon fault, the development of the broad, complexly faulted Dune Wash graben, and the convergence of several block-bounding faults along the west side of Busted Butte. Scott (1990) expressed the southward increase in deformation as an increase in the area underlain by imbricate fault zones characterized by steeper eastward dips of strata and an imbricate pattern of closely spaced, steep, west-dipping faults with minor, down-to-the-west offsets of a few meters or less. Clockwise vertical-axis rotations of Paintbrush Group strata increase from north to south, from $5^{\circ}$ to $10^{\circ}$ in the central block of the Central Yucca Mountain domain, to $30^{\circ}$ at the extreme south end of Yucca Mountain, south of the map area (Rosenbaum and others, 1991). Northwest- to north-northwest-striking splays are a common component of the north-striking block-bounding fault systems. In some places, these northwest-striking splays have developed into major relay faults that transfer displacement between block-bounding faults. In the extreme southern part of Yucca Mountain (south of the map area), the strikes of the southern Windy Wash and Stagecoach Road block-bounding faults are rotated to northeasterly orientations, and the subsidiary splays strike north (Simonds and others, 1995).

Tertiary extension in the Yucca Mountain area occurred primarily between 16 and $10 \mathrm{Ma}$ (Carr, 1984, 1990; Scott, 1990; Hudson and others, 1994, 1996). Evidence for pre-Paintbrush Group (pre-12.8 Ma) deformation along the block-bounding faults is buried by the tuffs of the Paintbrush Group themselves. Older units are sparsely exposed either within or adjacent to the map area. As reviewed by Carr (1990), the Timber Mountain-Oasis Valley caldera complex, which was the source for most of the tuffs of the Paintbrush Group, lies within an older, north-trending rift zone, which he named the Kawich-Greenwater rift. This older rift basin formed within the Walker Lane belt and controlled the locus of caldera structures in the southwestern Nevada volcanic field (fig. 1 of Carr, 1990).

There is indirect evidence that the Solitario Canyon fault was active during eruption of the Paintbrush Group. One clear pre-Tiva Canyon Tuff growth fault, a splay off the Solitario Canyon fault, is well exposed along the eastern canyon wall midway along Solitario Canyon southwest of borehole $\mathrm{H}-5$. The nonwelded units appear to thicken across that fault, consistent with a growth-fault setting. Throw at the top of the Topopah Spring Tuff is about $10 \mathrm{~m}$, decreasing upsection to less than $4 \mathrm{~m}$ at the base of the Tiva Canyon Tuff, and dying out in the upper part of the Tiva Canyon Tuff.

Another example of extensional deformation during deposition of the Paintbrush Group is exposed on the west flank of Fran Ridge. A small north-trending graben structure, presumably kinematically related to the Paintbrush Canyon fault, is filled with pre-Tiva Canyon Tuff nonwelded bedded tuff (unit bt), which thickens in the center of the graben. Faults related to the graben, however, do not extend upward into the overlying Tiva Canyon Tuff.

The basal contact of the 11.6-Ma Rainier Mesa Tuff is one of the key horizons to unraveling the timing of tectonism in the Yucca 
Mountain area. There appears to be an eastward decrease in the amount of angular unconformity at the base of the Rainier Mesa Tuff. Fridrich (in press) has shown that a significant angular unconformity exists between the Rainier Mesa Tuff and the underlying Tiva Canyon Tuff west of Yucca Mountain in northern Crater Flat (west of the map area). He deduced that there was a significant pulse of regional east-west extension recorded by the angular unconformity.

The basal contact of the Rainier Mesa Tuff is exposed locally in northern Windy Wash in the western part of the map area. There, the bedded tuff (unit bt5) dips about $8^{\circ}-10^{\circ}$ more steeply than the overlying Rainier Mesa Tuff, supporting the formation of a gentle angular unconformity after deposition of the Paintbrush Group rocks (post-12.7 Ma), but prior to eruption and emplacement of the Rainier Mesa. In this same area, the Rainier Mesa is caught up in the Windy Wash fault zone, faulted against Yucca Mountain Tuff and Pah Canyon Tuff. It was present when the major displacement occurred along the Northern Windy Wash fault, which has the most displacement of any blockbounding fault in the map area (over $450 \mathrm{~m}$ ). This evidence indicates that the Northern Windy Wash fault was active both before and after deposition of the Rainier Mesa Tuff and, therefore, had a protracted history of motion.

The basal contact of the Rainier Mesa Tuff is preserved farther to the east in the Solitario Canyon area at Plug Hill, where evidence is lacking to support a major angular unconformity at the base of the Rainier Mesa. Compaction foliations within the Tiva Canyon Tuff dip at about $12^{\circ}$ to the east, an alignment similar in magnitude to the dip of the welding contact in the overlying Rainier Mesa. This is contrary to mapping by Scott and Bonk (1984), who depicted the basal contact of the Rainier Mesa down-cutting into the top of the Tiva Canyon Tuff, a geometry that implies a significant amount of erosion and post-Tiva Canyon, preRainier Mesa deformation. The "down-cutting" depicted by Scott and Bonk (1984) is simply a down-to-the-southwest fault that cuts the Tiva Canyon and Rainier Mesa, as was mapped originally by Lipman and McKay (1965). Therefore, there is no significant amount of erosion beneath this contact at Plug Hill.

On the eastern side of the map area, the basal contact of the 11.6-Ma Rainier Mesa Tuff is exposed on the southwestern side of Dune Wash, just west of Ambush Pass. There, the contact is conformable between a bedded tuff (unit bt5) and the top of the Tiva Canyon Tuff. Additionally, the bedded tuff (unit bt5) is conformably overlain by a bedded basal horizon in the base of the Rainier Mesa. Above this nonwelded bedded horizon within the Rainier Mesa Tuff, distinguished from unit bt5 by vitric pumice, lies a nonwelded massive horizon that may have a structural discordance of $5^{\circ}-8^{\circ}$ with its bedded basal horizon. This apparent change in dip is internal to the Rainier Mesa Tuff.

The distribution of the Rainier Mesa Tuff is key to understanding the Tertiary tectonic history of Yucca Mountain. In the western part of the region, it caps the top of ridge crests. In the central and eastern parts, the Rainier Mesa is restricted to valley floors adjacent to the major block-bounding faults. Moreover, except near Plug Hill, the Rainier Mesa is further restricted to the hanging-wall areas of the blockbounding faults and does not lap onto the footwall. At Plug Hill, the Rainier Mesa does lap across older faults associated with the Solitario Canyon fault. The Rainier Mesa appears to be conformable in a west-dipping hanging-wall block associated with the Iron Ridge fault (north of borehole WT-11). Its absence from the footwall areas cannot be explained by erosion alone inasmuch as the Rainier Mesa Tuff also forms resistant erosional remnants on ridge crests in the western part of the map area. Its general restriction to the hanging walls of the blockbounding faults indicates that it was erupted prior to the final phases of motion on those faults and was downdropped thereafter. If it were simply erupted into preexisting valleys and grabens (Carr, 1986; Scott, 1990) then it would lap consistently onto the footwall of the blockbounding faults, which are also in the valley floors. This is in keeping with the mapping of the Timber Mountain-Oasis Valley caldera complex, in which the Rainier Mesa Tuff is highly faulted within and adjacent to the caldera complex (Byers and others, 1976).

In summary, there is evidence for a protracted history of Tertiary extensional deformation in the Yucca Mountain area. Pre-Paintbrush Group extension formed a buried north-striking rift in which the Timber Mountain-Oasis Valley caldera complex formed. Syn-Paintbrush Group (circa $12.7 \mathrm{Ma}$ ) extension occurred along minor structures related to the Solitario Canyon and Paintbrush Canyon faults. Evidence for continued extension along the block-bounding faults and rotation of units is recorded by an angular unconformity beneath the 11.6-Ma Rainier Mesa Tuff in the northwestern part of the map area. In addition, the Rainier Mesa Tuff overlaps faults within the Solitario Canyon fault zone at Plug Hill, indicating post-Tiva Canyon, pre-Rainier Mesa motion on this block-bounding fault. To 
the east, however, the basal contact of the Rainier Mesa is conformable with the underlying 12.7-Ma Tiva Canyon Tuff. This suggests a westward increase in extension earlier than 11.6 Ma within the map area. Extension along the block-bounding faults continued after deposition of the Rainier Mesa Tuff inasmuch as its current preservation is restricted to the hanging walls and faulted by the block-bounding faults.

\section{REFERENCES CITED}

Broxton, D.E., Chipera, S.J., Byers, F.M., Jr., and Rautman, C.A., 1993, Geologic evaluation of six nonwelded tuff sites in the vicinity of Yucca Mountain, Nevada, for a surfacebased test facility for the Yucca Mountain Project: Los Alamos National Laboratory Report LA-12542-MS, 83 p.

Broxton, D.E., Warren, R.G., Byers, F.M., Jr., and Scott, R.B., 1989, Chemical and mineralogical trends within the Timber Mountain-Oasis Valley caldera complexEvidence for multiple cycles of chemical evolution in a long-lived silicic magma system: Journal of Geophysical Research, v. 94, p. 5961-5986.

Buesch, D.C., Dickerson, R.P., Drake, R.M., II, and Spengler, R.W., 1994, Integrated geology and preliminary cross section along the north ramp of the Exploratory Studies Facility, Yucca Mountain: 5th International High Level Radioactive Waste Management Conference, v. 2, p. 1055-1065.

Buesch, D.C., Nelson, J.E., Dickerson, R.P., Drake, R.M., II, Spengler, R.W., Geslin, J.K., Moyer, T.C., San Jaun, C.A., and Felger, T., 1995, Distribution of lithostratigraphic units within the central block of Yucca Mountain, Nevada-A three-dimensional computer-based model, version YMP.R2.0: U.S. Geological Survey OpenFile Report 95-124, 61 p.

Buesch, D.C., Spengler, R.W., Moyer, T.C., and Geslin, J.K., 1996, Proposed stratigraphic nomenclature and macroscopic identification of lithostratigraphic units of the Paintbrush Group exposed at Yucca Mountain, Nevada: U.S. Geological Survey OpenFile Report 94-469, 45 p.

Byers, F.M., Jr., Carr, W.J., Orkild, P.P., Quinlivan, W.D., and Sargent, K.A., 1976, Volcanic suites and related cauldrons of Timber Mountain-Oasis Valley caldera complex, southern Nevada: U.S. Geological Survey Professional Paper 919, $69 \mathrm{p}$.

Carr, M.D., Waddell, S.J., Vick, G.S., Stock, J.M., Monsen, S.A., Harris, A.G., Cork,
B.W., and Byers, F.M., Jr., 1986, Geology of drill hole UE-25p\#1-A test hole into preTertiary rocks near Yucca Mountain, southern Nevada: U.S. Geological Survey OpenFile Report 86-175, 87 p.

Carr, W.J., 1984, Regional structural setting of Yucca Mountain, southwestern Nevada, and Late Cenozoic rates of tectonic activity in part of the southwestern Great Basin, Nevada and California: U.S. Geological Survey Open-File Report 84-854, 108 p.

1986, Volcano-tectonic setting of Yucca Mountain and Crater Flat, southwestern Nevada, in Carr, M.D., and Yount, J.C., eds., Geologic and hydrologic investigations of a potential nuclear waste disposal site at Yucca Mountain, southern Nevada: U.S. Geological Survey Bulletin 1790, p. 35-49.

1990 , Styles of extension in the Nevada Test Site region, southern Walker Lane Belt-An integration of volcano-tectonic and detachment fault models, in Wernicke, B.P., ed., Basin and Range extensional tectonics near the latitude of Las Vegas, Nevada: Geological Society of America Memoir 176, p. 283-303.

-1992, Structural model for western Midway Valley based on RF drillhole data and bedrock outcrops, in Gibson, J.D., and others, eds., Summary and evaluation of existing geological and geophysical data near prospective surface facilities in Midway Valley, Yucca Mountain Project: Sandia National Laboratories SAND 90-491, 94 p.

Carr, W.J., and Parrish, L.D., 1985, Geology of drill hole USW $\mathrm{VH}-2$, and structure of Crater Flat, southwestern Nevada: U.S. Geological Survey Open-File Report 85-475, $41 \mathrm{p}$.

Christiansen, R.L., and Lipman, P.W., 1965, Geologic map of the Topopah Spring Northwest quadrangle, Nye County, Nevada: U.S. Geological Survey Geologic Quadrangle Map GQ-444, scale 1:24,000.

Day, W.C., Potter, C.J., Sweetkind, D.S., and Dickerson, R.P., 1996, Detailed bedrock geologic map of the central block area, Yucca Mountain-Implications for structural development of the potential high-level radioactive waste repository area in Nye County, Nevada: Geological Society of America Abstracts with Programs, v. 28, no. 7 , p. A-248.

Day, W.C., Potter, C.J., Sweetkind, D.S., Dickerson, R.P., and San Juan, C.A., 1998, Bedrock geologic map of the central block area, Yucca Mountain, Nye County, Nevada: U.S. Geological Survey Miscella- 
neous Investigations Series I-2601, scale 1:6,000, 2 plates.

Dickerson, Robert, 1996, Geologic and geophysical evidence for normal faulting in Yucca Wash, Yucca Mountain, Nevada: Geological Society of America Abstracts with Programs, v. 28, no. 7, p. A-191 to A192.

Dickerson, R.P., and Drake, R.M., II, 1995, Source of the rhyolite at Comb Peak, southwest Nevada volcanic field: Geological Society of America Abstracts with Programs, v. 27 , no. 4 , p. 8 .

1998, Geologic map of the Paintbrush Canyon area, Yucca Mountain, Nevada: U.S. Geological Survey Open-File Report 97-783, 2 plates, scale 1:6,000.

Dickerson, R.P., and Spengler, R.W., 1994, Structural character of the northern segment of the Paintbrush Canyon fault, Yucca Mountain, Nevada, in High level radioactive waste management, Proceedings of the Fifth Annual International Conference, Las Vegas, Nevada, May 22-24, 1994: LaGrange Park, Ill., American Nuclear Society, v. 4, p. 2367-2372.

Fridrich, C.J., in press, Tectonic evolution of Crater Flat basin, Yucca Mountain, Nevada: Geological Society of America Special Paper.

Geldon, A.L., 1993, Preliminary hydrogeologic assessment of boreholes UE-25c\#1, UE$25 \mathrm{c} \# 2$, and UE-25c\#3, Yucca Mountain, Nye County, Nevada: U.S. Geological Survey Water-Resources Investigations Report 92-4016, 85 p.

Geslin, J.K., and Moyer, T.C., 1995, Summary of lithologic logging of new and existing boreholes at Yucca Mountain, Nevada, March 1994 to June 1994: U.S. Geological Survey Open-File Report 94-451, 16 p.

Geslin, J.K., Moyer T.C., and Buesch, D.C., 1995, Summary of lithologic logging of new and existing drill holes at Yucca Mountain, Nevada, August 1993 to February 1994: U.S. Geological Survey Open-File Report 94-342, 39 p.

Gibson, J.D., Swan, F.H., Wesling, J.R., Bullard, T.F., Perman, R.C., Angell, M.M., and DiSilvestro, L.A., 1992, Summary and evaluation of existing geological and geophysical data near prospective surface facilities in Midway Valley, Yucca Mountain Project: Sandia National Laboratories SAND 902491, $94 \mathrm{p}$.

Hansen, W.R., 1991, Suggestions to authors of the reports of the United States Geological Survey: U.S. Geological Survey, 7th Edition, 289 p.
Hudson, M.R., Minor, S.A., and Fridrich, C.J., 1996, The distribution, timing, and character of steep-axis rotations in a broad zone of dextral shear in southwestern Nevada: Geological Society of America Abstracts with Programs, v. 28 , no. 7 , p. A-451.

Hudson, M.R., Sawyer, D.A., and Warren, R.G., 1994, Paleomagnetism and rotation constraints for the middle Miocene southwestern Nevada volcanic field: Tectonics, v. 13, no. 2, p. 258-277.

Langenheim, V.E., and Ponce, D.A., 1994, Gravity and magnetic investigations of Yucca Wash, southwest Nevada, in High level radioactive waste management, Proceedings of the Fifth Annual International Conference, Las Vegas, Nevada, May 22-24, 1994: LaGrange Park, Ill., American Nuclear Society, v. 4, p. 2272-2278.

Langenheim, V.E., Ponce, D.A., Oliver, H.W., and Sikora, R.F., 1993, Gravity and magnetic study of Yucca Wash, southwest Nevada: U.S. Geological Survey Open-File Report 93-586-A, 14 p.

Lipman, P.W., and McKay, E.J., 1965, Geologic map of the Topopah Spring Southwest quadrangle, Nye County, Nevada: U.S. Geological Survey Geologic Quadrangle Map GQ-439, scale 1:24,000.

Moyer, T.C., Geslin, J.K., and Buesch, D.C., 1995, Summary of lithologic logging of new and existing boreholes at Yucca Mountain, Nevada, July 1994 to November 1994: U.S. Geological Survey Open-File Report 95-102, $27 \mathrm{p}$.

Moyer, T.C., Geslin, J.K., and Flint, L.E., 1996, Stratigraphic relations and hydrologic properties of the Paintbrush Tuff nonwelded (PTn) hydrologic units, Yucca Mountain, Nevada: U.S. Geological Survey Open-File Report 95-397, 151 p.

Muller, D.C., and Kibler, J.E., 1985, Preliminary analysis of geophysical logs from the WT series of drill holes, Yucca Mountain, Nye County, Nevada: U.S. Geological Survey Open-File Report 86-46, 30 p.

Neal, J.T., 1986, Preliminary validation of geology at a site for repository surface facilities, Yucca Mountain, Nevada: Sandia National Laboratories SAND 85-0815, 54 p.

O'Neill, J.M., Whitney, J.W., and Hudson, M.R., 1992, Photogeologic and kinematic analysis of lineaments at Yucca Mountain, NevadaImplications for strike-slip faulting and oroclinal bending: U.S. Geological Survey Open-File Report 91-623, 23 p.

Ponce, D.A., 1994, Geophysical investigations of concealed faults near Yucca Mountain, 
southwest Nevada, in High level radioactive waste management, Proceedings of the Fifth Annual International Conference, Las Vegas, Nevada, May 22-24, 1994: LaGrange Park, Ill., American Nuclear Society, v. 4, p. 168-174.

- 1996, Interpretive geophysical fault map across the central block of Yucca Mountain, Nevada: U.S. Geological Survey Open-File Report 96-285, 15 p., 4 plates.

Ponce, D.A., and Langenheim, V.E., 1994, Preliminary gravity and magnetic models across Midway Valley and Yucca Wash, Yucca Mountain, Nevada: U.S. Geological Survey Open-File Report 94-572, 25 p.

Ponce, D.A., Langenheim, V.E., and Sikora, R.F., 1993, Gravity and magnetic data of Midway Valley, southwest Nevada: U.S. Geological Survey Open-File Report 93540-A, 7 p.

Poole, F.G., Carr, W.J., and Elston, D.P., 1965, Salyer and Wahmonie Formations of southeastern Nye County, Nevada, in Contributions to stratigraphy 1965: U.S. Geological Survey Bulletin 1224-A, p. A36-A44.

Potter, C.J., Day, W.C., and Sweetkind, D.S., 1996, Structural evolution of the potential high-level nuclear waste repository site at Yucca Mountain, Nevada: Geological Society of America Abstracts with Programs, v. 28 , no. 7, p. A-191.

Rosenbaum, J.G., Hudson, M.R., and Scott, R.B., 1991, Paleomagnetic constraints on the geometry and timing of deformation at Yucca Mountain, Nevada: Journal of Geophysical Research, v. 96, p. 1963-1979.

Sawyer, D.A., Fleck, R.J., Lanphere, M.A., Warren, R.G., Broxton, D.E., and Hudson, M.R., 1994, Episodic caldera volcanism in the Miocene southwestern Nevada volcanic field-Revised stratigraphic framework, 40 Ar/39 Ar geochronology, and implications for magmatism and extension: Geological Society of America Bulletin, v. 106, p. 1304-1318.

Sawyer, D.A., and Sargent, K.A., 1989, Petrologic evolution of divergent peralkaline magmas from the Silent Canyon caldera complex: Journal of Geophysical Research, v. 94 , p. 6021-6040.
Scott, R.B., 1990, Tectonic setting of Yucca Mountain, southwest Nevada, in Wernicke, B.P., ed., Basin and range extensional tectonics near the latitude of Las Vegas, Nevada: Geological Society of America Memoir 176, p. 251-282.

Scott, R.B., Bath, G.D., Flanigan, V.J., Hoover, D.B., Rosenbaum, J.G., and Spengler, R.W., 1984, Geological and geophysical evidence of structures in northwest-striking washes, Yucca Mountain, southern Nevada, and their possible significance to a nuclear waste repository in the unsaturated zone: U.S. Geological Survey Open-File Report 84-567, $23 \mathrm{p}$.

Scott, R.B., and Bonk, J., 1984, Preliminary geologic map of Yucca Mountain, Nye County, Nevada, with geologic sections: U.S. Geological Survey Open-File Report 84-494, scale 1:12,000.

Simonds, F.W., Whitney, J.W., Fox, K.F., Ramelli, A.R., Yount, J.C., Carr, M.D., Menges, C.M., Dickerson, R.P., and Scott, R.B., 1995, Map showing fault activity in the Yucca Mountain area, Nye County, Nevada: U.S. Geological Survey Miscellaneous Investigations Series Map I-2520, scale $1: 24,000$.

Spengler, R.W., Braun, C.A., Linden, R.M., Martin, L.G., Ross-Brown, D.M., and Blackburn, R.L., 1993, Structural character of the Ghost Dance fault, Yucca Mountain, Nevada, in High level radioactive waste management, Proceedings of the Fourth Annual International Conference, Las Vegas, Nevada, April 26-30, 1993: LaGrange Park, Ill., American Nuclear Society, v. 1, p. 653-659.

Spengler, R.W., Braun, C.A., Martin, L.G., and Weisenberg, C.W., 1994, The Sundance fault-A newly recognized shear zone at Yucca Mountain, Nevada: U.S. Geological Survey Open-File Report 94-49, 11 p.

Spengler, R.W., and Rosenbaum, J.G., 1980, Preliminary interpretations of geologic results obtained from boreholes UE-25a-4, -5, -6 , and -7 , Yucca Mountain, Nevada Test Site: U.S. Geological Survey Open-File Report 80-929, $33 \mathrm{p}$.

Stewart, J.H., 1980, Geology of Nevada: Nevada Bureau of Mines and Geology, Special Publication 4, $136 \mathrm{p}$. 


